\title{
Measurement Model of Teaching Competency of Secondary School Teachers in Malaysia
}

\author{
https://doi.org/10.3991/ijet.v14i20.11465 \\ Mat Rahimi Yusof ${ }^{(\varpi)}$, Mohd Faiz Mohd Yaakob \\ Universiti Utara Malaysia, Kedah, Malaysia \\ mrahimiyeuum.edu.my \\ Mohd Yusri Ibrahim \\ Universiti Malaysia Terengganu, Terengganu, Malaysia
}

\begin{abstract}
Competent teachers are the most important capital in boosting the nation's education system in line with other developed countries in the world. This quantitative study aims to develop a model for measuring the teaching competency of a secondary school teacher in Malaysia. This measurement model has contained three functions namely (i) teaching and learning strategies, (ii) teacher and student communication, and (iii) teachers' professionalism value. The results of confirmatory factor analysis from the collected data through 352 respondents that were analyzed by SEM AMOS found that 17 of the 20 suggested behaviors are acceptable. This finding was verified the proposed function within the teaching competence variables. Finally, a successful teachers' teaching competency measurement model has been developed and can be used to any responsible parties to encourage and in-crease competency among teachers.
\end{abstract}

Keywords - Teaching Competency; Communication; Teachers' Professionalism

\section{Introduction}

The Ministry of Education puts a clear direction in the Malaysia Educational Blue Print (2013-2025) in order for the national education system moving along with developed countries. In addition to education transformation, principals, supporting infrastructure, and community involvement, teachers are the most important asset in the effort to propel our nation's education system to a higher level [1].

Thus, competent teachers are the most important capital in boosting nation's education system along with the other developed countries in the world. However, in education system in Malaysia, relatively there has not been a standard of teachers' teaching competency like the other developed countries such as United State of America, United Kingdom, Japan, Australia dan Netherland [2]-[6].

But, the initiative of the Bahagian Pendidikan Guru (BPG) has successfully developed a Standard Guru Malaysia (SGM) document which can be used as a basis to 
improve the quality of service of the teaching profession to achieve the predetermined quality. It can also be used as the basis of standard teaching competence of teachers.

To address the challenges of the 21 st century education of academic qualifications, basic training and existing experience are still inadequate. Recognizing this fact the government introduced a Pelan Pembangunan Profesionalisme Berterusan (PPPB) aimed at developing professional competence towards strengthening the desired attributes so that teachers and school leaders can effectively and effectively deliver their roles and responsibilities [7].

The PPPB model is based on three-dimensional competencies, five attributes and six roles and responsibilities of teachers and school leaders. PPPB has placed two phases namely the initial phase and phase of capacity building as well as continuous expertise throughout the service period. The initial phase involves teachers who are first appointed in the service until they have confirmed the position of the goal to be developed the competence of teachers in the real situation. The capacity building phase begins after the teacher is confirmed to the post service. This phase aims to develop competencies to achieve expertise in teaching and learning and education leadership [7].

\section{Literature Review}

As mentioned before, no more standard of teachers' teaching competency in education system in Malaysia. However, many local researchers conducted their study about teachers' teaching competency in term of one of the role and task of teachers is to facilitate student learning, while students expect teachers to effectively teach their achievement[8]-[10].

Overall, local researchers found that the level of teachers' teaching competency was at moderate level and high level in teaching methods and teaching aids but still weak in aspects of pedagogical competence, relevant knowledge and skills [2], [11][13].

In the context of teaching skills competence, the findings of this decade researcher show that the overall perception of the students is that teachers need to the mastering of learning evaluation skills followed by the diversity of teaching strategies and the use of information technology skills in order to enhance student achievement [14].

In addition, teachers need to master in using information technology and digital technology in their teaching and learning. Studies by local researchers demonstrate the competence of using information technology and digital technology to attract students, motivate students and improve understanding of students [15]-[18].

In the context of the competence of the use of information and communication technology in teaching and learning, the findings show that there is a significant relationship between teacher attitude towards the use of TMK in teaching [19].

Based on the literature review, it can be concluded that there is a diversity of dimensions or aspects in the teaching competence of teachers. Among them are aspects of pedagogy, knowledge and skills as well as teaching aids. This diversity shows that 
in Malaysia there is no standard set of teacher teaching competencies that teachers can guide in Malaysia[2].

Based on literature review and issues in teachers' competency, this study proposes three constructs of teacher's teaching competency as illustrated in the conceptual framework as in Figure 1. Teachers' teaching competency is a variable followed by three construct namely teaching and learning strategy, teacher and student communication and teachers' profesionalisme value.

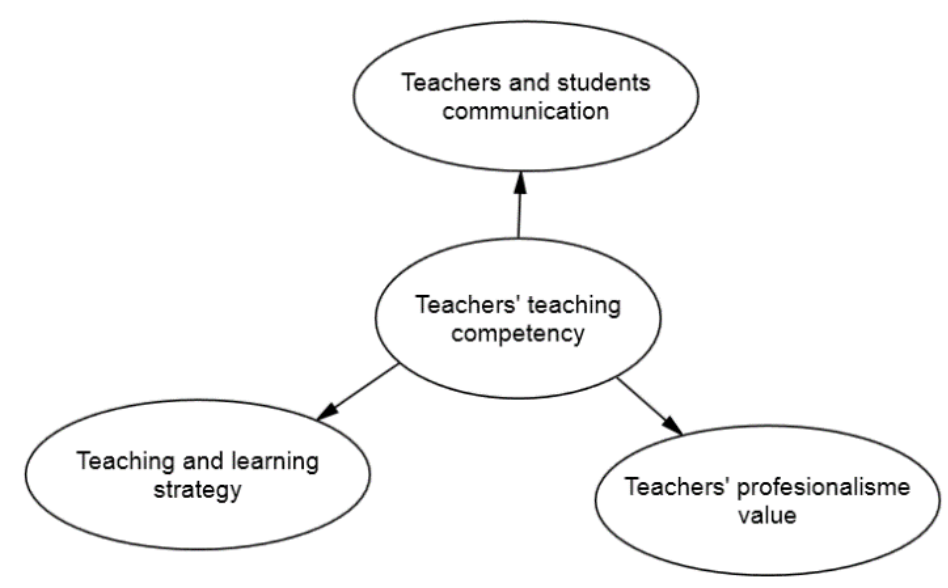

Fig. 1. The conceptual framework

\section{Measurement}

This quantitative study was applied cross sectional survey aims to develop a model for measuring the teaching competency of secondary school teacher in Malaysia. The participants consist of 352 teachers which represented the secondary school in Malaysia. Data was collected by using questionnaire which using five-scale responses, starting from the lowest scale, "never" to the highest scale which is "very frequent". Data were analyzed using Structural Equation Modelling (SEM). To validate the proposed factor for each dimension, Confirmatory Factor Analysis (CFA) is performed. The proposed factor is acceptable if the factor loading value is 0.708 [20]. However, according to Hair (2012) the external load value $\geq 0.4$ is acceptable if the AVE value reaches the recommended value of $>0.5$. For composite reliability the value $>0.708$ is acceptable (Hair et al, 2012).Next, the fitness of model were tested using several fit indices such as Khi Square (CMIN), CFI, RMSEA, PNFI and PCFI. The hypothesis model was considered fitting to the collected data when the significant value of Khi Square exceeding 0.05. Hypothesized model is also considered fit when the CFI exceeding 0.90 , but values between 0.80 and 0.89 is still in the acceptable margin. The RMSEA value also considered accepted if smaller than 0:08, but still acceptable if less than 0.1 (Byrne, 1998). The model also considered fit when PCFI and PNFI value exceeds 0.5 (Meyers et al. Al, 2006). The hypothesis model is considered to corre- 
spond to the study data when the value of $\chi 2$ is not significant ie above 0.05 [21], [22].

\section{$4 \quad$ Finding}

Table 1 shows the values of FL, C.R, AVE and $\sqrt{ }$ AVE obtained for teachers' teaching competency variables. FL, CR, AVE and $\sqrt{ } \mathrm{AVE}$ values for NPG $(\mathrm{FL}=0.380$ $0.818, \mathrm{CR}=0.83, \mathrm{AVE}=0.51, \sqrt{ } \mathrm{AVE}=0.66), \mathrm{KPdP}(\mathrm{FL}=0.655-0.769, \mathrm{CR}=0.86$, $\mathrm{AVE}=0.53, \sqrt{\mathrm{AVE}}=0.73)$ and $\mathrm{KGM}(\mathrm{FL}=0.282-0.814, \mathrm{CR}=0.6394, \mathrm{AVE}=$ $0.35, \sqrt{ } \mathrm{AVE}=0.59)$. But after item NPG7 is deleted the value of FL, C.R, AVE and $\sqrt{A V E}(\mathrm{FL}=0.511-0.818, \mathrm{C} . \mathrm{R}=0.83, \mathrm{AVE}=0.0 .50, \sqrt{\mathrm{AVE}}=0.71)$ are increasing. Similarly with KGM, after items KGM4 and KGM 5 are deleted FL, C.R, AVE and $\sqrt{ } \mathrm{AVE}$ values for $\mathrm{KGM}$ to be $(\mathrm{FL}=0.454-0.790, \mathrm{C} . \mathrm{R}=0.74, \mathrm{AVE}=0.52, \sqrt{\mathrm{AVE}}=$ 0.72 ) also are increasing.

Table 1. FL, C.R, AVE AND $\sqrt{ }$ AVE values for teachers' teaching competency

\begin{tabular}{|c|c|c|c|c|c|}
\hline Constructs & Items & FL & C.R & AVE & $\sqrt{ } \mathbf{A V E}$ \\
\hline \multirow{8}{*}{$\begin{array}{l}\text { Teacher's } \\
\text { professionalism } \\
\text { value } \\
(\mathrm{NPG})\end{array}$} & NPG1 & 0.516 & & & \\
\hline & NPG2 & 0.544 & & & \\
\hline & NPG3 & 0.718 & & & \\
\hline & NPG4 & 0.818 & 0.83 & 0.50 & 0.71 \\
\hline & NPG5 & 0.734 & & & \\
\hline & NPG6 & 0.696 & & & \\
\hline & NPG7 & 0.380 & \multicolumn{3}{|c|}{ Deleted due on low factor loading } \\
\hline & NPG8 & 0.511 & & & \\
\hline \multirow{7}{*}{$\begin{array}{l}\text { Teaching and learning skills } \\
\text { (KPdP) }\end{array}$} & KPP1 & 0.686 & & & \\
\hline & KPP2 & 0.691 & & & \\
\hline & KPP3 & 0.745 & & & \\
\hline & KPP4 & 0.742 & 0.86 & 0.53 & 0.73 \\
\hline & KPP5 & 0.693 & & & \\
\hline & KPP6 & 0.702 & & & \\
\hline & KPP7 & 0.631 & & & \\
\hline \multirow{5}{*}{$\begin{array}{l}\text { Teachers and students communica- } \\
\text { tion } \\
(\text { KGM) }\end{array}$} & KGM3 & 0.454 & & & \\
\hline & KGM1 & 0.794 & 0.722 & 0.52 & 0.72 \\
\hline & KGM2 & 0.770 & & & \\
\hline & KGM4 & 0.264 & \multicolumn{3}{|c|}{ Deleted due on low factor loading } \\
\hline & KGM5 & 0.357 & \multicolumn{3}{|c|}{ Deleted due on low factor loading } \\
\hline
\end{tabular}

Based on table 1, CFA results show that overall factor loading (FL) values are acceptable except for items NPG7 (FL= 0.380), KGM4 (FL=0.264) and KGM5 $(F L=0.357)$ which have low FL values. To confirm it, FL, C.R, AVE and $\sqrt{A V E}$ values are noted.

Next table 2 shows the values of FL, C.R, AVE and $\sqrt{ }$ AVE for each construct in teacher's teaching competency. All constructs were rated FL, C.R, AVE and VAVE values $(\mathrm{FL}=0.807$ to $0.921, \mathrm{C} . \mathrm{R}=0.91, \mathrm{AVE}=0.77, \sqrt{ } \mathrm{AVE}=0.88)$. This finding 
confirms that all the suggested constructs in the teacher's teaching competence are accepted.

Table 2. FL, C.R, AVE and $\sqrt{ }$ AVE for each constructs in Teachers' Teaching Competency

\begin{tabular}{|c|c|c|c|c|c|c|}
\hline Constructs & & Variable & FL & C.R & AVE & $\sqrt{ }$ AVE \\
\hline NPG & $<---$ & KPG & 0.807 & & & \\
\hline KPdP & $<---$ & KPG & 0.921 & 0.91 & 0.77 & 0.88 \\
\hline KGM & $<---$ & KPG & 0.903 & & & \\
\hline
\end{tabular}

Next, based on table 3, the overall function and behavior accepted in teacher's teaching competency (function $=3$, behavior $=17$ ). While the behavior is rejected for teachers' teaching competency (behavior $=3$ ).

Table 3. Summary CFA analysis for Teachers' Teaching Competency

\begin{tabular}{|c|c|c|c|}
\hline \multirow{2}{*}{ Variable } & Constructs & $\begin{array}{c}\text { Accepted } \\
\text { Behaviour }\end{array}$ & $\begin{array}{c}\text { Rejected } \\
\text { Behaviour }\end{array}$ \\
\hline \multirow{3}{*}{ Teachers' Teaching Competency } & NPG & 7 & 1 \\
\cline { 2 - 4 } & KGM & 3 & 2 \\
\cline { 2 - 4 } & KPdP & 7 & 0 \\
\cline { 2 - 4 } & Total & $\mathbf{1 7}$ & $\mathbf{3}$ \\
\hline
\end{tabular}

Fig. 2 show the final measurement model of teachers' teaching competency among teachers in Malaysia. The hypothesis model was considered fitting to the collected data when all fit indices are acceptable (CFI=.917, RMSEA=.076, PNFI=.775 and $\mathrm{PCF}=.745)$.

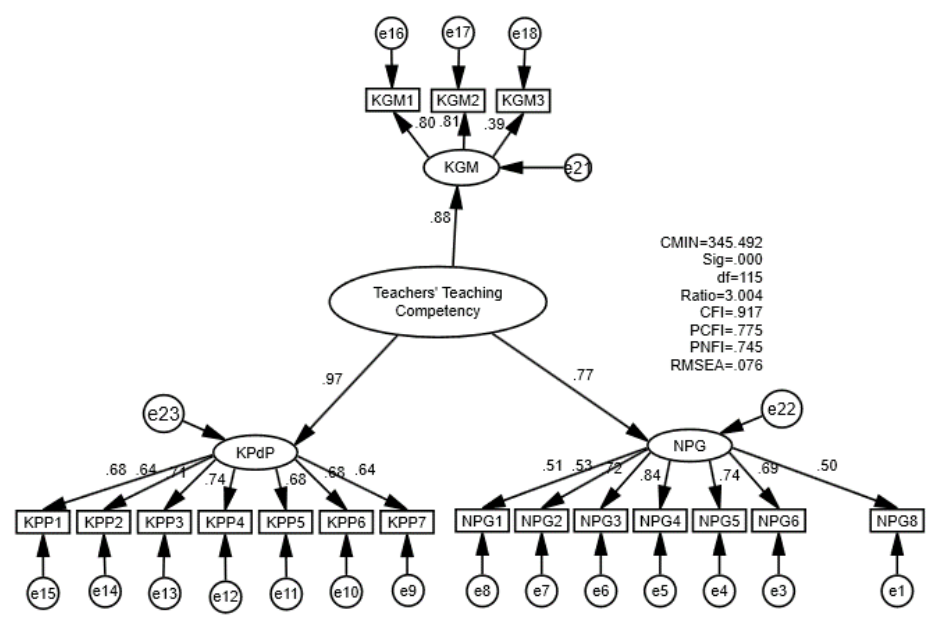

Fig. 2. The final measurement model of teachers" teaching competency 
Finally, a successful teachers' teaching competency measurement model as shown as figure 2 has been developed and can be used by any responsible parties to encourage and increase competency among teachers.

\section{Discussion}

The main purpose of this study is to develop a model for measuring the teaching competency of secondary school teacher in Malaysia. CFA result was successful developed measurement model teachers' teaching competency of secondary school teacher in Malaysia. The result shows that three functions namely (i) teaching and learning strategies, (ii) teacher and student communication, and (iii) teachers' professionalism value and 17 behaviors of teachers' teaching competency were validated. Apart from being able to confirm the competence of teacher teaching proposed in SGM, these study findings also act as a value added to the constructs of teacher teaching competencies previously identified by the researchers.

The findings show that the three behavior of teachers' teaching competency were deleted. Hence, teachers needs to improve their knowledge and technology skills especially in the context communication and teaching strategies. In this case it is recommended that the authorities increase the training to the teachers in improving their teaching competency. In conclusion, it is time to set a standard of teachers' teaching competency in Malaysia along with other developed countries in the world.

\section{References}

[1]M. Y. Nurahimah and O. Rafisah, "Hubungan kualiti penyeliaan pengajaran dan pembelajaran di bilik darjah dengan efikasi guru," Asia Pacific J. Educ. Educ., vol. 25, pp. 53-71, 2010.

[2]I. Mohammed Sani and S. Saedah, "Standard Kompetensi Guru Malaysia," 2012. [Online]. Available: http://www.fp.utm.my/ePusatSumber/listseminar/medc2012/pdf/159.pdf.

[3]M. R. Yusof and M. Y. Ibrahim, "Model kepimpinan pengajaran maya dan kompetensi pengajaran guru," in 4th Regional Conference on Educational Leadership and Management, 2015.

[4]M. R. Yusof, "Pembinaan model kepimpinan instruksional maya, pola komunikasi dan kompetensi pengajaran guru sekolah menengah di Malaysia," Universiti Malaysia Terengganu, 2017.

[5]M. R. Yusof, M. Y. Ibrahim, and S. A. Rahim, "The relationship between virtual instructional leadership and teaching competency," Int. J. Acad. Res. Bus. Soc. Sci., vol. 7, no. 8, pp. 146-156, 2017.

[6]M. R. Yusof, M. Y. Ibrahim, and S. A. Rahim, "Virtual instructional leadership and teachers teaching competency: Mediated by communicationpattern,” Int. J. Acad. Res. Bus. Soc. Sci., vol. 7, no. 8, pp. 96-108, 2017.

[7]Ministry of Education, Malaysia Education Blueprint 2013 - 2025. Putrajaya: Ministry of Education, 2013. 
[8]A. G. Muhammad Faizal and W. Julie, "Harapan murid bemasalah terhadap pengajaran guru:Satu kajian awal di sebuah negara maju," J. Kurikulum Pengajaran Asia Pasifik, vol. 2, no. 1, pp. 26-43, 2014.

[9]M. Sharil, A. Rahimah, and A. Hussein, "Kepimpinan instruksional di sekolah berkesan dalam menjana modal insan cemerlang," in KepimpinanPengetua Menjana Modal Insandi SekolahBerkesan, Shahril @ Charil Marzuki, Rahimah Ahmad, and Hussein Ahmad, Eds. Batu Caves: PTS Profesional, 2010, pp. 265-280.

[10]A. Noor Erma and K. E. Leong, "Hubungan anatara sikap, minat, pengajaran guru dan pengaruh rakan sebya terhadap pencapaian matematik tambahan tingkatan 4," J. Kurikulum Pengajaran Asia Pasifik, vol. 2, no. 2, pp. 1-10, 2014.

[11]I. Hamdi, T. Ab Halim, A. M. Rosadah, and B. Safari, "Amalan Pengajaran Guru dalam Pengajaran dan Pembelajaran Pendidikan Islam di Sekolah Kebangsaan Pendidikan Khas ( Masalah Pendengaran ),” J. Islam. Arab. Educ., vol. 4, no. 2, pp. 11-24, 2012. https://doi. org/10.17576/akad-2016-8602-02

[12]Y. Azizi, H. Shahrin, and M. A. Fadhlina, "Tahap Kompetensi Guru Sekolah Rendah Terhadap Pengajaran Sains Dan Matematik Dalam Bahasa Inggeris,” eprints UTM, pp. 1-21, 2010. https://doi.org/10.11113/jt.v53.116

[13]M. I. Farisi, "Guru Pintar Online: Sumber dan Ruang Belajar Guru untuk Peningkatan Kualitas Kompetensi dan Profesionalisme,” in Simposium Nasional, 2012, pp. 1-15. https://doi.org/10.31227/osf.io/765dr

[14]A. Anuar and J. Nelson, "Pengaruh Kompetensi Kemahiran Guru Dalam Pengajaran Terhadap Pencapaian Akademik Pelajar Dalam Mata Pelajaran Sejarah,” J. Kurikulum Pengajaran Asia Pasifik, vol. Bil 1, no. 2, pp. 20-31, 2013.

[15]A. R. Hasnuddin, Z. Norfaizuryana, and A. K. Nor Azzarahton, "Keberkesanan Penggunaan ICT di Dalam Pengajaran Dan Pembelajaran Pendidikan Islam Bagi Sekolah Kebangsaan Desa Pandan Kuala Lumpur,” in International Conference on Imformation Technology \& Society, 2015, no. June, pp. 238-252.

[16]T. C. Keong and A. Carol, "Pengaplikasian video Youtube: Bahan bantu mengajar (BBM) dalam proses pengajran dan pembelajaran mata pelajaran Sains Sosial," in Seminar Pendidikan Sejarah dan Geografi 2013, 2013, pp. 29-30.

[17]M. S. Rajamoney, "Computer Supported Colloborative Learning (CSCL0 in E-PAL projects to enhance ESL writing among secondary school students in Malaysia," in Seminar Kebangsaan Majlis Dekan IPTA 2012, 2012.

[18]R. Ramakrishnan and A. Siti Hawa, "Penggunaan sumber digital Sejarah dalam kalangan guru Sejarah," in Seminar Kebangsaan Majlis Dekan Pendidikan IPTA 2012, 2008.

[19]I. Rohayati, M. A. Ahmad Fauzi, and T. Othman, "Hubungan antara kompetensi guru, sokongan dan prasarana sekolah dengan sikap guru terhadap penggunaan teknologi maklumat dan komunikasi dalam pengajaran dan pembelajaran,” J. Pendidik. Sains Mat. Malaysia, vol. 2, no. 1, pp. 51-64, 2012. https://doi.org/10.33084/anterior.v16i1.76

[20]J. F. Hair, M. Sarstedt, T. M. Pieper, and C. R. M., "The Use of Partial Least Squares Structural Equation Modeling in Strategic Management Research: A Review of Past Practices and Recommendations for Future Applications," Long Range Plann., vol. 45, no. 5-6, pp. 320-340, 2012. https://doi.org/10.1016/j.lrp.2012.09.008

[21]L. S. Meyers, G. Gamst, and A. J. Guarino, Applied multivariate research: Design and interpretation., Second Edi. London: Sage Publication, 2013.

[22] Y. P. Chua, Kaedah dan statistik penyelidikan buku 5: Ujian regresi, analisis faktor dan analisis SEM. Kuala Lumpur: Mc Graw Hill Education, 2014. 


\section{$7 \quad$ Authors}

Mat Rahimi Yusof is an educational lecturer from Universiti Utara Malaysia. He has more than 20 years of teaching experience in school. His research interest in educational administration, communication and financial management in education.

Mohd Faiz Mohd Yaakob is a Senior Lecturer at the School of Education and Modern Languages, College of Arts and Sciences, Universiti Utara Malaysia. He has more than 10 years of teaching experience in school. His research interest areas are Educational Planning \& Policy, Educational Administration and Islamic Studies.

Mohd Yusri Ibrahim is a Senior Lecturer from Universiti Malaysia Terengganu (UMT). He brings to his training sessions and workshops with varied professional experience of more than 10 years. His research interest in leadership, educational administration, and communication.

Article submitted 2019-08-23. Resubmitted 2019-09-14. Final acceptance 2019-09-17. Final version published as submitted by the authors. 